\title{
Production of Quinoa (Chenopodium quinoa) in the Marginal Environments of South Mediterranean Region: Nile Delta, Egypt
}

\author{
Amal H. Mahmoud \\ Laboratory of Saline and Alkaline Soils Research, Institute of Soil, Water and \\ Environment Research, Agricultural Research Center, Alexandria, Egypt
}

\begin{abstract}
TNTRODUCING new crops to the marginal environments of south meditrranean region represnts one of the challenges to struggling the expected results of climate change on water quality and availability and on soil salinization. Quinoa as a halophyte was introduced to be one of strategic plants which can successfuly grow under the climatic conditions of north coast of Nile Delta, Egypt. The effects of sowing dates and various levels of water salinity on plant growth and yield of quinoa were examined. Sowing of quinoa at the beginning of winter season (last quarter of December where maximum air temperature was 18.8 and minimum was $8.2{ }^{\circ} \mathrm{C}$ ) resulted in higher plant height, biomass and seed yields comparing with the sowing at second quarters of December and January. The optimum growth was associated with relative humidity about $68.8 \%$ and daylight cumulative hours about 1819 and cumulative sunshine hours about 977. Maximum yield of both biomass and seed resulted from plants irrigated with fresh water $(\mathrm{EC}=0.65 \mathrm{dS} \mathrm{m}-1)$ and reductions in biomass and seed yields were observed with the increasing water salinity. But weight of 1000 seed increased as water salinity increased. Regardless the sowing date and/or water salinity, symptoms of powdery mildew disease (PMD) were observed on the quinoa leaves at about 53 days after sowing and progressed in appearance. The high percentages of relative humidity could be the major cause of spreading the disease in quinoa. The results of statistical ANOVA showed that biomass yield was significantly affected by sowing date whereas seed yield was markedly affected by water salinity. The study concluded to the possibility of cultivation of quinoa plant in salt affected soils in northern Nile Delta agricultural areas successfully as one of the solutions for the exploitation of marginal environments with the need for more studies related in ways that raise productivity through fertilizer transactions under the high irrigation water salinity conditions.
\end{abstract}

Keywords : South Meditterranean Region, Marginal environments, Quinoa, Sowing date, Water salinity, and Powdery mildew.

\section{Introduction}

In the Mediterranean basin, the expected climatic changes by the year 2050 for the southern Mediterranean countries where rainfall decreases by $10-15 \%$, temperature increases by $1.25-$ $2.5^{\circ} \mathrm{C}$ and more salinization of coastal aquifers may cause detrimental effects on agricultural production sector (Ragab and Prudhomme, 2002 and Wang et al., 2003) and more deterioration in land and water resources will be expected and, consequently, severe environmental factors will adversely affect plant growth and sustainability of agricultural development.
The water scarcity, climate change and population bombing crises are considered tremendous problems in Egypt and the increasing of food production under these circumstances is the major aim of policy decision-makers. Therefore, looking for additional irrigation water resources for agricultural production tended to recycling agricultural drainage water and treated wastewater for covering water requirements (Allam et al., 2016 and Barnes, 2014). Saline water is another low-quality water resource that can be used for irrigation purposes but under certain conditions. 
Introducing salt-tolerant plants and halophytes to agricultural marginal environments (salt affected soils and/or low-water quality irrigated areas) is one of strategic solutions to cope the population-food scarcity gap (Daoud et al. 2016 and Rozema \& Scha, 2013). Quinoa is considered a halophytic grain crop (Turcios et al., 2016 and Ruiz et al., 2016) grown in various climatic zones (Jacobsen et al., 2012) and can tolerate the stresses of drought and soil and/or water salinity (Wu et al., 2016 and Amjad et al., 2015). Quinoa has a huge genetic variability and flexibility, tolerance to biotic and abiotic stresses, and ability to adapt to adverse soil and climatic conditions in places where most agriculture is marginal (Garcia et al., 2015). Grains of quinoa are used instead of wheat grains in bread and other bakeries production (Abou-Zaid et al., 2012 and Koehler et al., 2014) and quinoa seeds and hull are used successfully as fodder (Resero et al., 2010 and Jacobsen et al., 1997 and Carlsson et al., 1984).

In Egypt, very few research trials for quinoa cultivation were conducted in Wadi El-Natroun region (Behairah Governorate), South Sinai Governorate and Matrouh Governorate (Shams, 2011). These regions are characterized by climatic conditions relatively different from the North Nile Delta region, particularly in relative humidity and physicochemical and hydrological properties of marginal land. Therefore, the objective of the current work concentrates on introducing quinoa as a potential halophytic cash crop for marginal soils of coastal areas of south Mediterranean and examines the optimum dates for cultivation under saline irrigation water conditions.

\section{Materials and Methods}

Quinoa (Chenopodium quinoa) seeds of Regalona genotype were obtained from Desert Research Center, Cairo, Egypt. Under greenhouse growth conditions, quinoa was cultivated in $1.6 \mathrm{x}$ $0.7 \mathrm{~m}^{2}$ plots containing clay-textured soil collected from Abis, Alexandria (see Table 1 for selected soil properties) in two rows where the distance between rows were 50 and between plants $30 \mathrm{~cm}$. After surface-mixing of phosphate and potassium fertilizers by the rate of 30 and $25 \mathrm{~kg} \mathrm{P}_{2} \mathrm{O}_{5}$ and $\mathrm{K}_{2} \mathrm{O}$ per feddan in the forms of single superphosphate and potassium sulfate, respectively, five seeds were set at every point in each plot (every plot contains two rows and 8 plant sets). Quinoa was irrigated by three levels of water salinity: fresh water $\left(\mathrm{EC}=0.65 \mathrm{dS} \mathrm{m}^{-1}\right)$ and saline waters having $\mathrm{EC}=10$ and $20 \mathrm{dS} \mathrm{m}^{-1}$. Fresh water represents the tap water and saline water represents 100 and 200 $\mathrm{mM} \mathrm{NaCl}$ solutions. After 30 days of cultivation, plants were thinned to 2 per point and fertilized by $12.5 \mathrm{~kg} \mathrm{~N}$ per feddan in the form ammonium sulfate. Another two doses of $\mathrm{N}(12.5$ and $8 \mathrm{~kg}$ per feddan) were applied after 60 and 80 days of cultivation, respectively.

Due to the scarcity of information related to the time of germination in north Nile Delta, quinoa plants were cultivated in December, 9 and 19, 2015 and January 9, 2016. All above treatments were similarly repeated. The experiment was statistically designed as randomized complete blocks with four replicates.

TABLE 1. The main physico-chemical properties of soil used in the study.

\begin{tabular}{|c|c|c|}
\hline Properties & Value & Reference \\
\hline $\begin{array}{l}\text { Particle size distribution } \\
(\%) \text { : }\end{array}$ & & \\
\hline Sand & 6.21 & Gee and \\
\hline Silt & 18.2 & Bauder \\
\hline Clay & 75.59 & \\
\hline Soil texture: & Clay & \\
\hline $\begin{array}{l}\text { Total calcium carbonate } \\
(\%)\end{array}$ & 3.98 & $\begin{array}{l}\text { Nelson } \\
(1982)\end{array}$ \\
\hline $\begin{array}{l}\text { Cation exchange capacity } \\
\mathrm{CEC}\left(\mathrm{cmol} \mathrm{kg}^{-1}\right)\end{array}$ & 55.61 & $\begin{array}{l}\text { Rhoades } \\
\text { (1982 a) }\end{array}$ \\
\hline $\begin{array}{l}\text { Electrical conductivity } \\
\text { EC }\left(\mathrm{dS} \mathrm{m}^{-1}\right)\end{array}$ & 3.37 & $\begin{array}{l}\text { Rhoades } \\
(1982 \text { b) }\end{array}$ \\
\hline $\mathrm{pH}$ & 7.42 & $\begin{array}{l}\text { McLean } \\
(1982)\end{array}$ \\
\hline $\begin{array}{l}\text { Water soluble cations } \\
\left(\mathrm{meq} \mathrm{L}^{-1}\right)\end{array}$ & & $\begin{array}{l}\text { Rhoades } \\
(1982 \mathrm{~b})\end{array}$ \\
\hline $\mathrm{Ca}^{2+}$ & 11.4 & \\
\hline $\mathrm{Mg}^{2+}$ & 8.6 & \\
\hline $\mathrm{Na}^{+}$ & 14 & \\
\hline $\mathrm{K}^{+}$ & 0.35 & \\
\hline SAR & 4.44 & \\
\hline $\begin{array}{l}\text { Water soluble anions } \\
\left(\operatorname{meq} \mathbf{L}^{-1}\right)\end{array}$ & & $\begin{array}{l}\text { Rhoades } \\
(1982 \mathrm{~b})\end{array}$ \\
\hline $\mathrm{Cl}^{-}$ & 18.5 & \\
\hline $\mathrm{HCO}_{3}^{-}$ & 3.55 & \\
\hline $\mathrm{SO}_{4}^{2-}$ & 11.9 & \\
\hline
\end{tabular}

Egypt. J. Soil Sci. 57, No. 3 (2017) 
The meteorological data of the experimental site were daily recorded and included maximum and minimum air temperature, rainfall, relative humidity, hours of sunshine, wind speed and daylight hours. Beside the recorded meteorological data, the five-years records were obtained from the Central Lab. of Agricultural Climate, Agric. Res. Center (Giza, Egypt). At harvest (after 137, 131 and 135 day for sowing dates December 9 and 25, 2015 and January 19, 2016, respectively), plant height, fresh and dry biomass yield and seed yield were recorded. Obtained data were statistically analyzed using Costat software (Cohort, 1986).

\section{$\underline{\text { Results and Discussion }}$}

Effect of sowing date

A greenhouse trial was performed to estimate the effect of different sowing dates (9 and 25 December 2015 and 19 January 2016) on the progress of the growth and yield components of quinoa (Regalona cultivar, Table 2). The results showed that in the climatic conditions of North Nile Delta, Regalona cultivar is, generally, grown well in all tested sowing dates. At harvest, results of plant height showed that, quinoa sowed at December 25, 2015 gave the maximum values $(146.0 \mathrm{~cm})$ comparing with the plants sowed at Dec. $9(135.3 \mathrm{~cm})$ and Jan. $19(121.3 \mathrm{~cm})$. The sowing at approximately near the beginning of winter season (Dec. 25, 2015) gave higher averages of yields $\left(1026.8 \mathrm{~g} \mathrm{~m}^{-2}\right)$ for total biomass and $515.6(\mathrm{~g}$ $\mathrm{m}^{-2}$ ) for seed than the other two tested dates (Table 2). The same trend was observed with respect of the weight of 1000 seed where the highest weight $(2.97 \mathrm{~g})$ was obtained from quinoa sowed at Dec. 25, 2015 (Table 2).

According to the meteorological data (Fig.1) of the north Nile Delta, the maximum and

TABLE 2. Plant height, fresh weight of biomass, dry biomass and seed yields and weight of 1000 seed in response to sowing date and salinity of irrigation water. Values are presented as means of four replicates and values in the parentheses represent the standard deviation (SD)

\begin{tabular}{|c|c|c|c|c|c|c|}
\hline $\begin{array}{l}\text { Planting } \\
\text { Date }\end{array}$ & $\begin{array}{c}\text { Water } \\
\text { Salinity } \\
\left(d_{S} \text { m }^{-1}\right)\end{array}$ & $\begin{array}{l}\text { Plant Height } \\
\text { (cm) }\end{array}$ & $\begin{array}{c}\text { Fresh Biomass } \\
\text { yield }\left(\mathrm{g} \mathrm{m}^{-2}\right)\end{array}$ & $\begin{array}{l}\text { Dry Biomass } \\
\text { yield }\left(\mathrm{g} \mathrm{m}^{-2}\right)\end{array}$ & $\begin{array}{l}\text { Seed yield } \\
\quad\left(\mathrm{g} \mathrm{m}^{-2}\right)\end{array}$ & $\begin{array}{c}\text { Weight of } \\
1000 \text { seed }(g)\end{array}$ \\
\hline \multirow[t]{3}{*}{09 Dec 2015} & 0.6 & $135.3 \pm(6.3)$ & $1886.5 \pm(428.3)$ & $834.4 \pm(73.4)$ & $407.8 \pm(26.2)$ & $2.83 \pm(0.08)$ \\
\hline & 10 & $126.5 \pm(9.3)$ & $1981.0 \pm(182.5)$ & $738.3 \pm(76.3)$ & $360.4 \pm(21.0)$ & $3.33 \pm(0.20)$ \\
\hline & 20 & $111.5 \pm(6.8)$ & $1567.5 \pm(203.3)$ & $497.4 \pm(62.7)$ & $244.4 \pm(39.5)$ & $3.11 \pm(0.06)$ \\
\hline \multirow[t]{3}{*}{25 Dec 2015} & 0.6 & $146.0 \pm(5.6)$ & $2330.5 \pm(235.2)$ & $1026.8 \pm(120.1)$ & $515.6 \pm(71.9)$ & $2.97 \pm(0.05)$ \\
\hline & 10 & $141.5 \pm(10.0)$ & $1998.5 \pm(187.3)$ & $724.5 \pm(72.5)$ & $414.6 \pm(58.6)$ & $3.58 \pm(0.11)$ \\
\hline & 20 & $117.0 \pm(5.7)$ & $1655.5 \pm(138.8)$ & $5133 \pm(46.2)$ & $288.3 \pm(39.9)$ & $3.31 \pm(0.08)$ \\
\hline \multirow[t]{3}{*}{ 19 Jan 2016} & 0.6 & $121.3 \pm(18.7)$ & $1927.5 \pm(194.8)$ & $893.0 \pm(82.1)$ & $438.8 \pm(58.9)$ & $2.93 \pm(0.12)$ \\
\hline & 10 & $119.3 \pm(12.6)$ & $2032.0 \pm(417.8)$ & $712.8 \pm(142.2)$ & $349.0 \pm(71.9)$ & $3.35 \pm(0.17)$ \\
\hline & 20 & $104.8 \pm(12.4)$ & $1566.5 \pm(153.0)$ & $497.4 \pm(54.9)$ & $242.6 \pm(12.8)$ & $3.12 \pm(0.06)$ \\
\hline
\end{tabular}

minimum of air temperature ranged from 18.8 to 25.2 and from 8.0 to $17.2{ }^{\circ} \mathrm{C}$, respectively, in the period from December 9, 2015 to May 20, 2016. The total days from sowing to harvest were 142 , 132 and 116 for plants grown in Dec. 9 and 25, 2015 and Jan. 19, 2016, respectively.

The corresponded cumulative daylight hours for three tested dates were 1915, 1818.9 and $1539.4 \mathrm{hr}$. On the other hand the paralleled recorded cumulative sunshine hours were 1109 , 977 and 885 hr. Quinoa cultivars Regalona and Titicaca were cultivated successfully under Mediterranean climatic conditions (southern Italy) at the beginning of spring (Lavini et al., 2014).

\section{Effect of water salinity}

The results of yield and yield components listed in Table 2 showed that, in general, maximum yield of both biomass and seed resulted from plants irrigated with fresh water $(\mathrm{EC}=0.65$ $\mathrm{dS} \mathrm{m}^{-1}$ ) and lower yields were obtained as water salinity increased. About 11.5 to $27.7 \%$ reduction in total dry biomass resulted from the quinoa plots irrigated with water had $\mathrm{EC}=10 \mathrm{dS} \mathrm{m}^{-1}$ and further reductions (40-50\%) from those irrigated with water had EC $=20 \mathrm{dS} \mathrm{m}^{-1}$. Seed yield, also, was influenced by increasing water salinity where about 11.6 to $20.5 \%$ and 40 to $44.7 \%$ reductions in seed yield were recorded in the plots irrigated with water having EC 10 and $20 \mathrm{dS} \mathrm{m}^{-1}$, respectively. 

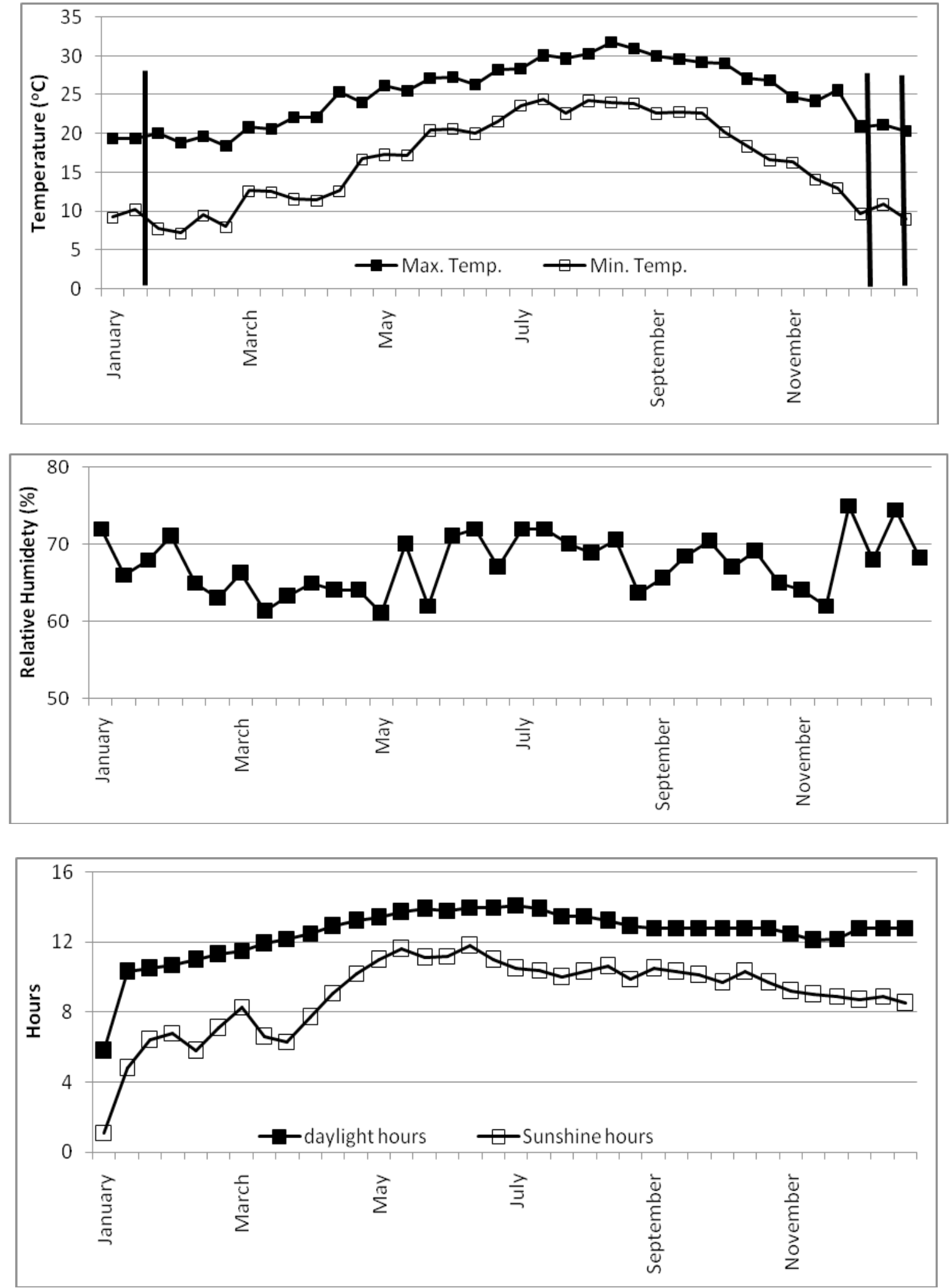

Fig.1. Averages of meteorological data of Alexandria station located in Abis and relevant to quinoa (CV Regalona) cultivation for all growth stages 
The weight of 1000 seed increased as salinity of irrigation water increased. Similar tendency was obtained by Lavini et al. (2014) for Titicaca and Regalona cultivars. Maximum increase was observed with quinoa treated with saline water having $\mathrm{EC}=10 \mathrm{dS} \mathrm{m} \mathrm{m}^{-1}$ for all tested sowing dates (Table 2) comparing with those irrigated

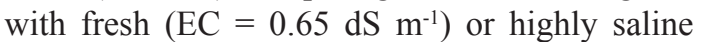

water $\left(\mathrm{EC}=20 \mathrm{dS} \mathrm{m}^{-1}\right)$. About 20.5 and $11.5 \%$ increases in the weight of 1000 seed of quinoa were obtained from the plots sown in Dec. 25, 2015 and irrigated with saline water had $\mathrm{EC}=10$ and $20 \mathrm{dS} \mathrm{m}^{-1}$, respectively, comparing with those obtained from fresh water-irrigated plots (Table 2 ). Figure 2 summarizes the results of yield and yield components of quinoa plants as a function of both sowing dates and water salinity.
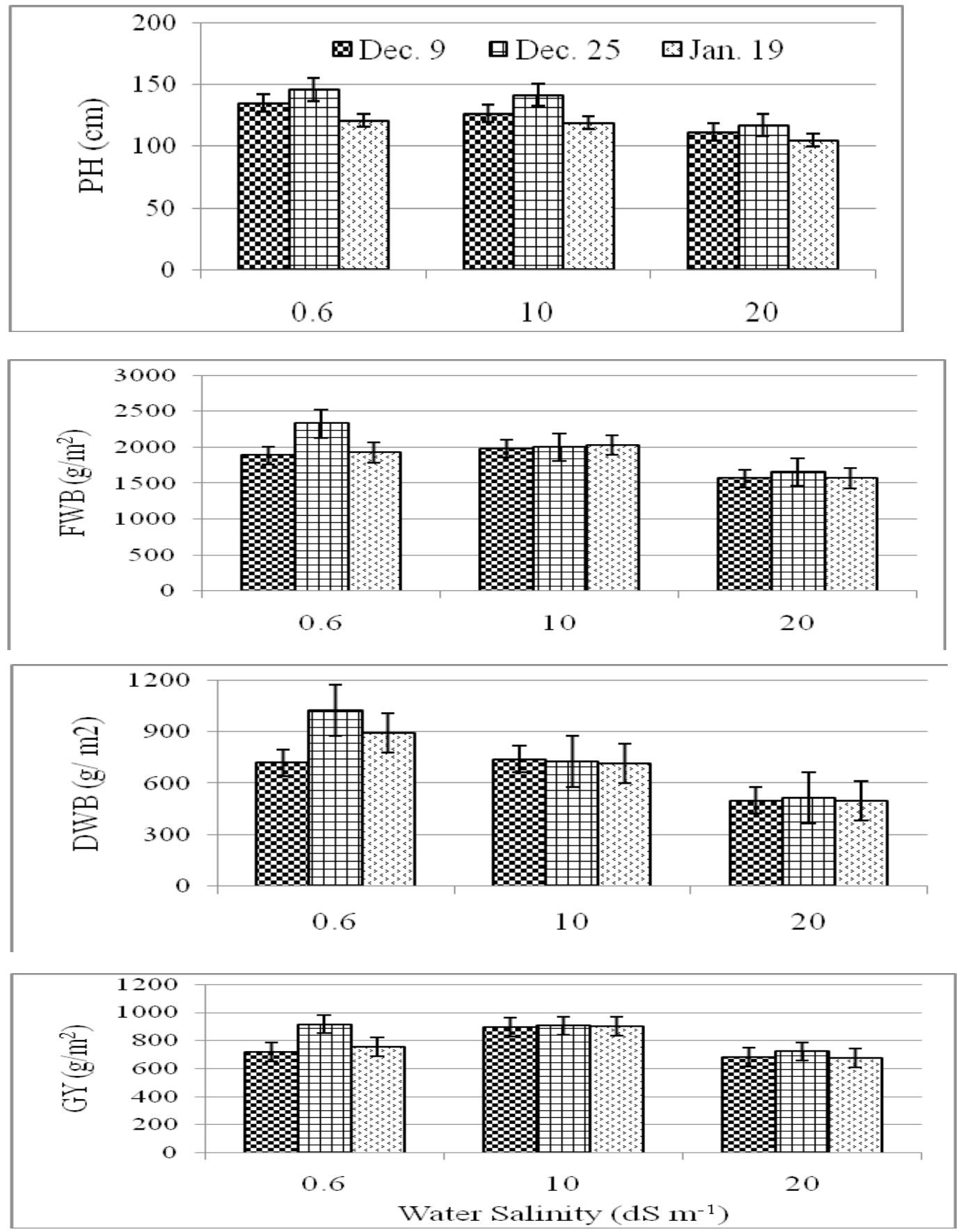

Fig. 2. Results of plant height (PH), fresh weight of biomass (FWB), dry weight of biomass (DWB) and seed yield (SY) of quinoa plant (Regalona cultivar) influenced by sowing date and irrigation water salinity. 
Appearance of powdery mildew disease (PMD)

Figure 3 showed that symptoms of PMD appeared on plant leaves in early vegetative stages and progressed in spreading with time. Both sowing date and level of water salinity had no influence on disease spreading and the increase in relative humidity ( $\mathrm{RH}$ ) would be expected the major factor encouraging the susceptibility of quinoa infection by PMD. According to Danielsen and Lubeck (2010), downy mildew of quinoa requires specific conditions for germination and infection. It proliferates in humidity above $80 \%$ and in cool temperatures between 15 and $20^{\circ} \mathrm{C}$. The records of RH and temperature in current study indicated that $\mathrm{RH}$ range from sowing to more than $50 \%$ of blooming (80-90 days after sowing) was $62-75 \%$ and minimum and maximum temperature ranged from 7.1 to 12.7 and from 16.5 to $25.2 \mathrm{oC}$, respectively, for the same period. In Denmark, Danielsen and Lubeck (2010) attributed the frequent founding of PMD on C. album to the close relationship to common weed species. In Egypt, El-Assiuty et al. (2014) recorded the first quinoa infection by PMD in two trials in Giza and Ismailia Governorate. They expected that this disease could be apotential constraint for quinoa production in Egypt. To minimize the effect of downy mildew on the seed yield, in depth studies are to bedone to develop control measures and accumulate information about disease parameters under local conditions.
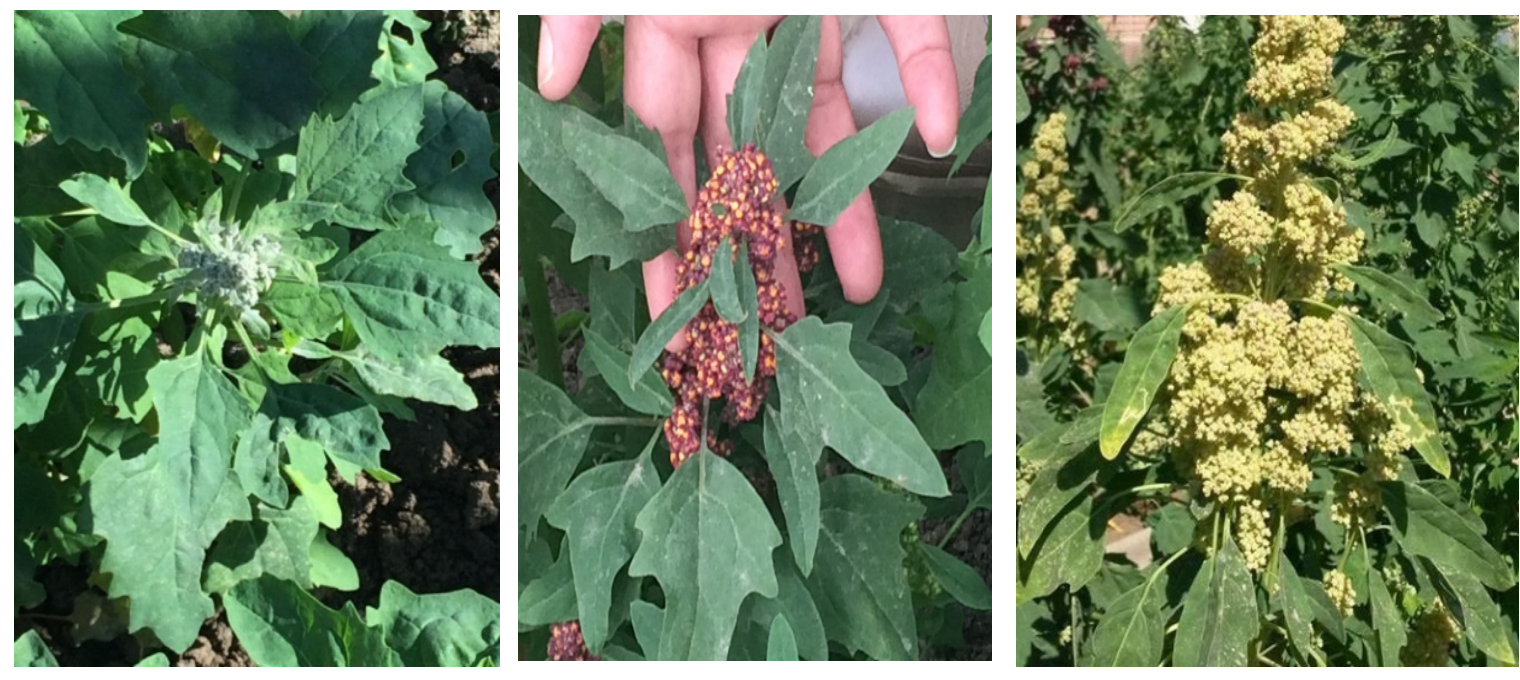

Fig. 3. Beginning (A) and progress (B and C) of Powdery Mildew disease symptoms appearance on the leaves of quinoa plants after 67, 87 and 107 of sowing day.

The analysis of variance (Table 3 ) shows that optimum agronomic parameters were resulted from the plant sowed in December 25 and irrigated with water had $10 \mathrm{dS}$ m-1. High significant effect of sowing date and water salinity on plant height and weight of 1000 seed was obtained. The biomass yield was significantly affected by sowing date whereas seed yield was markedly affected by water salinity. The interaction between sowing date and water salinity had no significant effect on all tested parameters.

\section{Conclusions}

From the recorded meteorological data, it seems that Regalona cultivar of quinoa grown optimally in the north coast of Nile Delta in the last quarter of December (beginning of winter season) with availability about 1900 and 1100 hours of daylight and sunshine. Regardless the relatively inhibition in quinoa biomass and seed yields as influenced by tested water salinity levels, the obtained yield was acceptable from the marginal land and water. On the other hand, further trials are required to overcome the decline in the biomass and seed yields under high soil and/or water salinity conditions such as N, P and $\mathrm{K}$ fertilization studies. Also, there is a need to hold the growth and cultivation experiments for other varieties of quinoa plants (other than Regalona genotype) under Mediterranean climate to identify their resistance to powdery mildew disease. 
TABLE 3. Analysis of variance for plant height $(\mathrm{cm})$, biomass and seed yields $(\mathrm{g})$ and weight of 1000 seed $(\mathrm{g})$ of quinoa Regalona as a result of sowing date and irrigation water salinity

\begin{tabular}{|c|c|c|c|c|c|}
\hline Factors & $\begin{array}{c}\text { Water } \\
\text { Salinity }\end{array}$ & $\begin{array}{l}\text { Plant } \\
\text { Height }\end{array}$ & $\begin{array}{l}\text { Biomass } \\
\text { Yield }\end{array}$ & $\begin{array}{l}\text { Seed } \\
\text { Yield }\end{array}$ & $\begin{array}{l}\text { Wt. of } 1000 \\
\text { Seed }\end{array}$ \\
\hline $\begin{array}{l}\text { Sowing Date (SD) } \\
09 \text { Dec } 2015 \\
25 \text { Dec } 2015 \\
\text { 19 Jan } 2016 \\
\text { LSD }_{0.05}\end{array}$ & $\begin{array}{c}0.65 \\
10 \\
20\end{array}$ & $\begin{array}{c}124.417 \mathrm{~b} \\
134.8 \mathrm{a} \\
115.1 \mathrm{c} \\
8.08\end{array}$ & $\begin{array}{c}690.0 \mathrm{a} \\
760.7 \mathrm{a} \\
701.1 \mathrm{a} \\
67.29\end{array}$ & $\begin{array}{c}340.0 \mathrm{~b} \\
406.2 \mathrm{a} \\
343.5 \mathrm{~b} \\
37.03\end{array}$ & $\begin{array}{c}3.007 \mathrm{~b} \\
3.290 \mathrm{a} \\
3.134 \mathrm{~b} \\
0.132\end{array}$ \\
\hline $\begin{array}{l}\text { Water Salinity (WS) } \\
\text { 09 Dec } 2015 \\
\text { 25 Dec } 2015 \\
\text { 19 Jan } 2016 \\
\text { LSD }_{0.05}\end{array}$ & $\begin{array}{c}0.65 \\
10 \\
20\end{array}$ & $\begin{array}{c}134.2 \mathrm{a} \\
129.1 \mathrm{a} \\
111.1 \mathrm{~b} \\
8.57\end{array}$ & $\begin{array}{c}918.0 \mathrm{a} \\
731.0 \mathrm{~b} \\
502.7 \mathrm{c} \\
67.29\end{array}$ & $\begin{array}{c}454.1 \mathrm{a} \\
377.2 \mathrm{~b} \\
258.5 \mathrm{c} \\
37.03\end{array}$ & $\begin{array}{c}2.910 \mathrm{c} \\
3.344 \mathrm{a} \\
3.177 \mathrm{~b} \\
0.132\end{array}$ \\
\hline $\begin{array}{l}\text { Significance } \\
\text { SD } \\
\text { WS } \\
\text { SD x WS }\end{array}$ & & $\begin{array}{c}* * * 1 \\
* * * 2 \\
\mathrm{~ns}^{3}\end{array}$ & $\begin{array}{c}* * * \\
\mathrm{~ns} \\
\mathrm{~ns}\end{array}$ & $\begin{array}{c}\mathrm{ns} \\
* * * \\
\mathrm{~ns}\end{array}$ & $\begin{array}{c}* * \\
* * * \\
\mathrm{~ns}\end{array}$ \\
\hline
\end{tabular}

$1-* * *$ : significant at 0.001 probability level, $2-* *$ : significant at 0.01 probability level and $3-$ ns: non significant.

\section{$\underline{\text { References }}$}

Abou-Zaid, A.A., El-Faham, S.Y. and Emam, W.H. (2012) Use of Quinoa meal to produce bakery products to Celiac and Autism Stuffs. Intern. J. Sci. and Res. 3, 1344-1354.

Allam, A., Tawfik, A., Yoshimura, C., and Fleifle, A. (2016) Simulation-based optimization framework for reuse of agricultural drainage water in irrigation. J. Environ. Manag. 172, 82-96.

Amjad, M., Akhtar, S. S., Yang, A., Akhtar, J. and Jacobsen, S.E. (2015) Antioxidative response of Quinoa exposed to iso-osmotic, ionic and non-ionic salt stress. J. Agron. \& Crop Sci. 201, 452-460.

Barnes, J. (2014) Mixing waters: The reuse of agricultural drainage water in Egypt . Geoforum, 57, 181-191.

Carlsson, R., Hanczakowski, P. and Kaptur, T. (1984) The quality of the green fraction of leaf protein concentrate from chenopodium quinoa willd. grown at different levels of fertilizer nitrogen. Animal Feed Sci. and Technol. 11, 239-245.

Cohort Software (1986) Graphics and Statistics Software for Scientists and Engineers. California, USA.
Danielsen, S. and Lubeck, M. (2010) Universally Primed-PCR indicates geographical variation of Peronospora Farinosaex. Chenopodium quinoa. $J$. Basic Microb. 50, 104-109.

Daoud, S., Elbrik, Kh., Tachbibi, N., Bouqbis, L., Brakez, M., and Harrouni, M.C. (2016) The Potential Use of Halophytes for the Development of Marginal Dry Areas in Morocco. In: M. A. Khan et al. (Ed.) Halophytes for Food Security in Dry Lands."pp: 141-156. Academic Press.

EL-Assiuty, E.M., Bekheet, F.M. and Fahmy, Z.M. (2014) First record of downy mildew of quinoa in Egypt. Egypt. J. Agric. Res., 92, 871-872.

Garcia, M., Condori, B., and Castillom, C. Del. (2015) Agro-ecological and Agronomic Cultural Practices of Quinoa in South America. In: K. Murphy and J. Matanguihan (Ed.) Quinoa: Improvement and Sustainable Production," First Edition. John Wiley \& Sons, Inc.

Gee, G.W. and Bauder, J.W. (1986) Prticle-size Analysis. In A. Klute (Ed.) "Methods of Soil Analysis: Part 1, Physical and Mineralogical Methods (second ed.)" Agronomy series Number (9), Amer. Soc. Agron., Amer. Soc. Soil Sci., Madisom, Wis., USA, pp: 383-411. 
Jacobsen, S.E., Jensen, C.R. and Liu, F. (2012) Improving crop production in the arid Mediterranean climate. Field Crops Res., 128, 34-47.

Jacobsen, E.E., Skadhauge, B., and Jacobsen, S.E. (1997) Effect of dietary inclusion of quinoa on broiler growth performance. Animal Feed Sci. Technol., 65, 5-14.

Koehler, P., Wieser, H., and Konitze, K. (2014) Celiac Disease and Gluten Multidisciplinary Challenges and Opportunities, pp. 173-213. Academic Press. UK

Lavini, A., Pulvento, C., d'Andria, R., Riccardi, M., Choukr-Allah, R., Belhabib, O., Yazar, A., Incekaya, C., Metin Sezen, S., Qadirand, M., and Jacobsen, S.E. (2014) Quinoa's Potential in the Mediterranean Region. J. Agro. Crop Sci., 200, 344-360.

McLean, E.O. (1982) Soil pH and Lime Requirement. In A. L. Page (Ed.) "Methods of Soil Analysis: Part 2, Chemical and Microbiological Properties (second ed.)" Agronomy series Number (9), Amer. Soc. Agron., Amer. Soc. Soil Sci., Madisom, Wis., USA, pp: 199-224.

Nelson, R.E. (1982) Carbonate and Gypsum. In A. L. Page (Ed.) "Methods of Soil Analysis: Part 2, Chemical and Microbiological Properties (second Ed.)" Agronomy series Number (9), Amer. Soc. Agron., Amer. Soc. Soil Sci., Madisom, Wis., USA, pp: 181-198.

Ragab, R. and Prudhomme, C. (2002) Climate change and water resources managementin arid and semiarid regions: prospective and challenges for the $21^{\text {st }}$ century. J. Biosystems Eng. 81, 3-34.

Rhoades, J.D. (1982 a) Cation Exchange Capacity. In A. L. Page (Ed.) "Methods of Soil Analysis: Part 2, Chemical and Microbiological Properties (second ed.)" Agronomy series Number (9), Amer. Soc. Agron., Amer. Soc. Soil Sci., Madisom, Wis., USA, pp: 149-158.

Rhoades, J.D. (1982 b) Soluble Salts. In A. L. Page (Ed.) "Methods of Soil Analysis: Part 2, Chemical and Microbiological Properties (second ed.)" Agronomy series Number (9), Amer. Soc. Agron., Amer. Soc. Soil Sci., Madisom, Wis., USA, pp: 167-180.
Rosero, O.L., Rosero, D.A., and Lukešová, D. (2010) Determination of the capacities of farmers to adopt quinoa grain (Chenopodium quinoa willd.) as potential feedstuff. Agricultura Tropicaet Subtropica. 43, 308-315.

Rozema, J. and Scha, H. (2013) Salt tolerance of halophytes, research questions reviewed in the perspective of saline agriculture. Environ. and Experim. Botany, 92, 83-95.

Ruiz, K.B., Aloisi, I., Duca, S.D., Canelo, V., Torrigiani, P., Silva, H., and Biondi, S. (2016) Salares versus coastal ecotypes of quinoa: Salinity responses in Chilean landraces from contrasting habitats. Plant Physiol. and Biochem.,101, 1-13.

Shams, A.(2011) Combat degradation in Rain Fed areas by introducing new drought tolerant crops in Egypt. Intern. J. Water Res. and Arid Environ., 1, 318-325.

Turcios, A.E., Weichgrebe, D., and Papenbrock, J. (2016) Potential use of the facultative halophyte Chenopodium quinoa willd. assubstrate for biogas production cultivated with different concentrations of sodium chloride under hydroponic conditions. Biores. Technol., 203, 272-279.

Wang, W.X., Vinocur, B., and Altman, A. (2003) Plant responses to drought, salinity andextreme temperatures: towards genetic engineering for stress tolerance. Planta, 218, 1-14.

Wu, G., Peterson, A. J., Morris, C.F. and Murphy, K.M. (2016) Quinoa seed quality response to sodium chloride and sodium sulfate salinity. Front. Plant Sci. 7, article 790, 1-8.

(Received : 3 / 12 /2016; acecpted : 22 / 1/2017) 


$$
\begin{aligned}
& \text { انتاج نبات الكينوا فى البيئات الهامشية لمنطقة جنوب المتوسط : شمال دلتا النيل ـ مصر } \\
& \text { قسم بحوث الأر اضى الملحية والقلوية ـ معهد بحوث الأراضى والمياه والبيئة ـ مركز البحوث الزر اعية ـ } \\
& \text { الاسكندرية - مصر. }
\end{aligned}
$$

إدخال محاصيل جديدة إلى البيئات الهامشية لمنطقة جنوب البحر المنوسط يمثل احد التحديات لمو اجهة النتائج

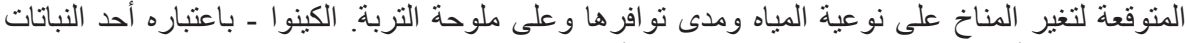

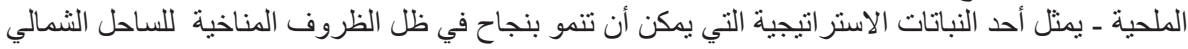
لالتا النيل، مصر.

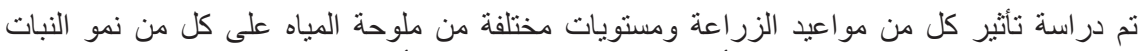

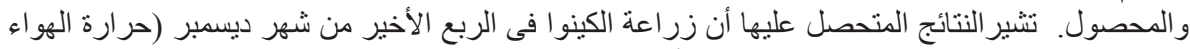

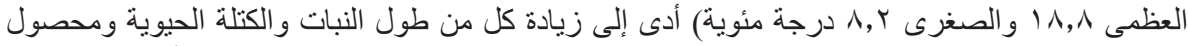

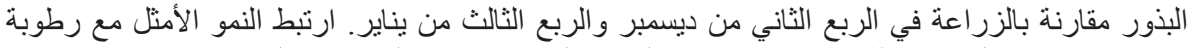

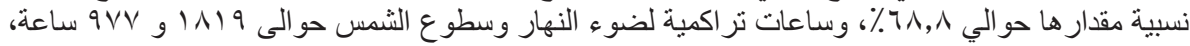

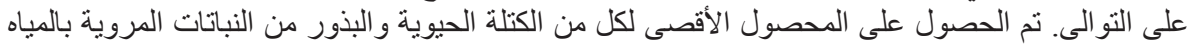

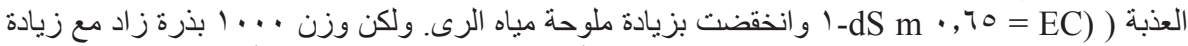

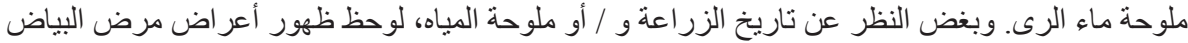

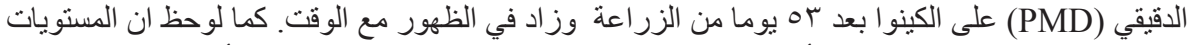

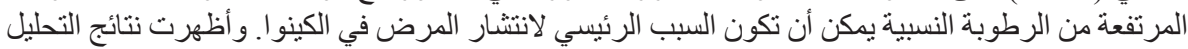

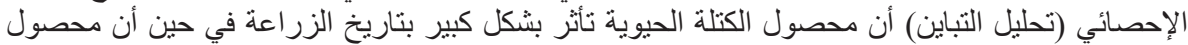

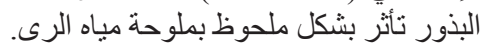

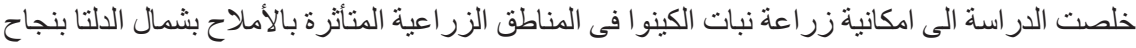

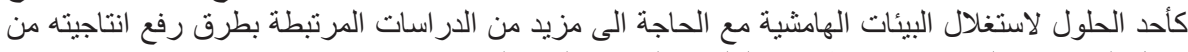

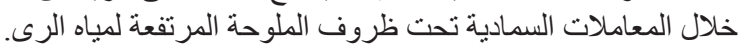

